\title{
Relational and Institutional Approaches to Planning Issues in Turkey
}

\author{
Türkiye'de Planlama Meseleleri Üzerine Kurumsal ve iliş̧kisel Yaklaşımlar
}

\author{
Özer KARAKAYACI
}

\section{ABSTRACT}

Planning discourses have focused on relational and institutional structure, as well as changing economic and social paradigms. This has led to alterations in various stages of planning systems, from theoretical approaches to institutional arrangements, spatial scales, local sources, and power relations and fragmentations, and from planning-implementation processes to political and public interests. Over the last two decades, there has been growing academic and political interest in the evolution of planning from the aforementioned perspectives in Turkey. The aim of the present study was to explore whether relational and institutional approaches are the key reasons for the success of planning approaches in upper-scale planning enterprises. It is demonstrated that insurmountable obstacles that provide reference for institutional and relational dimensions of planning are some of the most important matters impacting planning in Turkey. These obstacles include uncertain spatial scales, fragmentations of authority and territory, and incomplete institutional and legal regulation at regional and national levels, among other issues.

Keywords: Institutional restructuring; region; spatial scale; Turkey; upper-scale planning.

\section{ÖZ}

Ekonomik ve sosyal paradigmalarda yaşanan değişimle birlikte, planlama tartışmaları kurumsal ve ilişkisel boyutlar üzerine odaklanmıştır. Bu yaklaşım politik ve kamusal yatırımlardan planlama-uygulama süreçlerine, kuramsal ve kavramsal tartişmalardan kurumsal düzenlemelere, mekansal ölçeklere, yerel kaynaklara, güç ilişkileri ve parçalanmışlıklara bir çok aşamada planlama sisteminin değişimine yol açmıştır. Türkiye'de akademik ve politik tartişmalar da planlamanın kurumsal ve ilişkisel boyutundaki evrimini anlamaya ve kentsel/bölgesel gelişme üzerindeki yansımalarına odaklanmıştır. Bu bağlamda, makalede Türkiye'de üst ölçekli planlama deneyimlerinin kurumsal ve ilişkisel kapasiteden ne düzeyde beslendiği ve planlama süreçlerinin başarısı açısından kurumsal ve ilişkisel yaklaşımların anahtar bir faktör olup olmadığı araştırılmıştır. Çalışmanın sonucunda, Türkiye'de ulusal ve bölge düzeyinde tamamlanamamış yada belirsizlikler içerenkurumsal ve yasal düzenlemeler, belirsiz mekansal ölçekler ve yetki-otorite parçalanmaları gibi kurumsal ve ilişkisel boyuta referans veren konular bağlamında karşı karşıya kalınan sorunlar, planlama süreçlerindeki başarı düzeyini etkilemiştir.

Anahtar sözcükler: Kurumsal yeniden yapılanma; bölge; mekansal ölçek; Türkiye; üst ölçekli planlama. 


\section{Introduction}

Over the last two decades, there has been an overwhelming attention getting planning issues in both academic and policy society. Indeed, planning matters, especially upper-scale planning, focus on not only understanding conceptual discussions, but also understanding the process of change in institutional and relational structure of the planning system and organization. This matters can be based on three pillars: new planning concepts, planning systems and organizational structure within the context of new economic and social paradigms. This is because planning concepts such as regions, sustainability, competitiveness, innovation, and participation have required intensive changes to planning systems. Also planning systems and policies have particularly affected institutional capacity, which is linked directly to organizations in the planning process through paradigms. These include the following: horizontally integrated rather than vertically integrated, post-Fordist production models; economic structure based on networks (Davoudi, 2009: 141-142); dynamic spatial structure related to social and cultural processes; centres of strategic, social, economic and political concern in global networks (Haughton and Counsell, 2004: 42), In addition to new institutions and organizations with regional concepts having global effects (Keating, 1997 and 1998); postmodern trends leading to changes in strategies related to regional development (Amin, 1999a and 199b); and policy and informal institutions consisting of norms, values and behaviours (North, 1990).

This has led to the transformation in relational and institutional structure of planning systems in Turkey, with actions such as new legal regulations, the establishment of new institutions, new approaches at all scales of planning, governance and growing levels of public awareness. However, in upper-scale planning, ${ }^{1}$ due to considering political priorities over problemoriented approaches for planning, this restructuring has not carried into action. This is because dominating sectorial-spatial planning and normative region approaches, experiences dating to the 1960s, have continued to be the biggest obstacle for integrating planning process of relational structure fed by theoretical backgrounds, such as institutional and legal frameworks, new regionalism, strategic planning, participation and governance in planning. Likewise, this article

\footnotetext{
Concept of upper-scale planning in this study comprises region plans, regional development plans, strategic plans, strategic spatial plans consisting of politics, strategics and land-use decisions for several settlements at different scale. Hence, upper-scale planning sometimes refer to regional planning actions of Turkey in case of this paper.
}

seeks to eliminate growing problematic issues through new planning systems in Turkey.

This paper also seeks to explore what relational and institutional structure has matters for the success of upper-scale planning systems in Turkey. In other words, it is the aim of this paper to determine the effect of relational and institutional approaches on planning systems in the context of Turkey upperscale plans. This article discusses three main aspects of relational approaches: regionalism as a spatial dimension, institutionalism as governance for planning, and planning systems. In doing so, this paper is divided into five parts. In the first part, it explores the theoretical background, which has emerged from the planning concepts and planning systems of institutional approaches. This is followed by a discussion of the methodology by which the data is compiled and analysed. Thirdly, the case study draws on the architectural structure of upper-scale planning in Turkey, which define social, economic and spatial characteristics of plans prepared by actrors in certain period, and the institutional structure related to planning processes. The fourth part examines whether institutional and relational restructure has played a key role in the problems and successes of the upper-scale planning systems in Turkey. The final part concludes the discussion and make some recommendations.

\section{Theoretical Background: The Conceptual Discussions}

Over the last three decades, the increasing movement of capital and power beyond the borders of countries has led to significant changes in the conditions of economic growth and development. With effects of neoliberal agenda, this changes have resulted in the development of new expressions such as local entrepreneur initiatives, local dynamics and local mechanisms for decision processes. The structural changes in government and administrations as well as local characteristics and local-specific values have created opportunity and potential for planning systems. This is due to new spatial factors, informational/technological developments, social and cultural factors, regulation, governance, and so on.

In light of new spatial factors, place/region, as the main focus of upper-scale planning studies, has gained a different meaning in the paradigms. The concept of region, which not only is defined as 'closed', 'bounded' and a 'territorial entity', but also have become problematic and ambigious means for planning. This has been evaluated within the framework of relational and 
network-structured relations (Pike, 2009: 2). These new region approaches have given rise to many discussions related to the environmental, ecological, social, cultural, economic, administrative, institutional, and spatial dimensions, ranging from the sustainable usage or consumption of renewable and non-renewable environmental resources in the urban and rural production-consumption chain in the literature of regional development to decreasing the ecological footprint and the concept of planning with wide participation, in which political-administrative structuring and democratic organizations have concentric roles. Within the frame of all these developments, regulation and governance, being the main sources of planning systems, have arisen as an alternative method for managing collective affairs (Davoudi and Evans, 2005: 496). And region has been accepted as a basket of economic and regional development. There has been growing political and academic interest about how relational dimension provides the interactions between spatial scale and politics of regional development, and organization structure of planning. Therefore, theoretical framework has been handled three different level: region/regionalism as spatial dimension and politics of planning, new planning approaches as decision tools of economic paradigms, and institutional restructuring as organization models of planning systems.

\section{Region/New Regionalism}

Since the 1980s, regional politics have changed significantly as neoliberal agenda begun to dominate both the economic system and the social structure. With the crisis experienced in the 1970s, the region, which is the define spatial scale of planning, has reentered the scope of science fields examining the relationships between place and economic activities such as planners, economic geographers and economists. The region has experienced the change in terms of concept and content due to the regional development paradigms and new economic structure. Lipietz (1986: 21) summarises this situation as "the evaluations related to this stage are conducted in harmony with mechanisms that are consistent with one another; and the conditions of the transfer to the new stage begin to occur during the termination of the harmony among these mechanisms".

As a process of re-structuring in both the cultural structure and the regional development of politics has begun with the crises experienced in the economy since the 1970s, regions have been defined as places shaped not only according to natural and physical characteristics but also according to socio-cultural characteristics (MacLeod, 2001). A region, therefore, which is considered to be a whole spatial unit with strictly determined borders or as a piece of a nationstate at the level of industrialization has begun to be explained as a unit based on geographically embedded relations, networks, and border variables and in which the importance of spatial togetherness has decreased (Wheeler, 2002: 268). Regions appear as local devolution and a reflection of a new organization in which the central administrations would particularly like to decentralize social activities or organizations. In this period, regions have developed a new definition for spatial organization in which the nation-states have been affected by multi-national actors and processes (Keating, 1997: 19, Higano et.al., 2002: 1-3). In this process, "region"-based development models have become dominant over centralist development models. These models have been based on the approach of the 'third way' or 'new regionalism' occurring between Keynesian economic politics, which were developed for the purpose of regulating the distribution of income in less developed regions starting in the 1960s, and neoclassical market prediction of the transfer from regions with high cost to regions with low cost to maximize the profit of companies developed in the 1980s (Cumbers et.al., 2003: 327-328). These approaches, used as the third way or new regionalism, are expected to develop the regional economy by revealing the local resources of the regions themselves (Amin, 1999b: 392-395). Economic geographers such as M. Storper, P. Cooke, A. Amin, N. Thrift, R. Camagni, B. Asheim, and M. Gertler, support the third way approach, assert that a region or a social area can be defined by non-economic factors such as social capital, trust, face-to-face relationships, cooperation, spatial and social embeddedness, local habits and norms. This is because interactions relational approaches will ensure effective and efficient use of resources undetaking a significant role in regional development (Hadjimichalis, 2006: 692). For example, the studies of the pioneers of the literature of economic geography regarding social and relational factors, such as the social capital of Putnam and Coleman, the trust of Fukuyama, the untraded interdependencies of Storper and the institutional thicknesses of Porter, Amin and Thrift, undergo little deterioration from the Marxist viewpoint that critically considers the new regionalism approaches and the fact that social and cultural factors are ignored (Hadjimichalis, 2006: 692-693, MacLeod, 2001: 805). It has been discussed effects of new regionalism on the basis of the success of regions such as Silicon Valley, Third Italy, BadenWurttemberg. 
On the other hand, the discussions of the definition of physical space that have occurred as a result of the normative structure of the region and the ignorance of the socio-cultural dimension of the region have reinforced the assertion that new regionalism is an approach based on companies or sectors. Lovering, however, showes that the region is evaluated as single-dimensioned in an ultimately unclear and ambiguous structure, criticises new regionalism, which advocates the basis of social and economic life, makes the institutional structure more visible. He attempts to define the basic elements of in-region economic development such as information-thick and accumulation economies and institutional learning (Amin and Thrift, 1995: 93-95, Storper, 1999: 210-211, Cooke and Morgan, 1996: 94-96). Lovering, thus, has evaluated the paradigm of new regionalism to be far from an element of regional development because it depends on the normative principles of the region rather than its powerful structure of industry and the installation of state and social structure and lacks viewpoints associated with the relational structure of the region. He proposed that normative classifications at the nationalregional level are the most important barrier to deep analysis of the region. In contrast to the literature that sees the new regionalism approach as convincing with regard to regional development (Lovering 1998: 7-11). Despite these criticisms, new regionalism's discussion of including social and cultural factors in planning processes during the review of planning in the literature has been considered a key factor. In the new economic structure, although new regionalism has been evaluated as a firm and sector-based approach, especially with the critical approach introduced by the location's normative viewpoints, the efforts to associate location with non-spatial factors such as governance, participation, democracy, and cultural factors are viewed as a starting point for economic and regional development experiences.

\section{New Planning Approaches}

With the concept of the region changing due to the impact of global and neoliberal agenda, regional development politics have also changed with new paradigms, including the following: the new institutional and organizational structure; network-based spatial and economic organizations; dynamic spatial structure related to socio-cultural processes; strategic, social, economic and political developments; and horizontally integrated organization of production instead of vertically integrated organization of production. This change has affected not only the institutional structure related to the organization of the planning process but also the content and scope dimension of the planning and politics. The literature has discussed ways to eliminate the gaps and unclear events in the process of planning through spatial planning methods, which are accepted as the process of producing creative ideas related to how problematic areas can be reached with possible suggested solutions, providing a nuanced interpretation of structural problems and troubles that has begun to produce new politics integrated with new regionalism (Albrechts, 2004: 745). The procedures require institutional changes for the success of planning systems related to new theoretical and practical perspectives such as new regionalism, sustainability, and spatial planning in the nation-state. The growing literature on globalisation points to the importance of institutions and networks in regional growth and success.

This shows that the new planning system caused differentiation in organisational structure related to the management and application of the planning process in terms of spatial development with different viewpoints. This change required institutional restructuring with devolution. Institutional restructuring, especially in a regional agenda, reveals an organisation model for a new planning system through integration with existing institutional networks that evolve during the 'fallow period' of planning (Allmendinger and TewdwrJones, 2000:713, Baker, 1998).

At the same time, this is key method to the quality of regional development policies. For example, until the 2000s, the definition of sustainability in terms of environmental and physical factors, with relational results between environmental, economic and social factors defining the location, introduced to the agenda important discussions related to the institutional dimension of the planning process. The idea of sustainability has been defined as a development model directed by more than one component, namely social-cultural-economic, demographic, environmental and political factors, ranging from the sustainable usage or consumption of renewable and non-renewable environmental resources in production-consumption process to a broad participation-planning concept in which political-administrative and democratic organizations have concentric roles and from the urban population's equal use of fundamental human rights and income distribution to maintaining control of the urban demographic structure and development based on both exterior and interior potential and dynamics. This perspective reveals a new institutional restructuring for successful 
planning processes related to both planning systems and changes in the economic-social paradigm based on the effect of conceptual perspectives.

\section{Institutional Restructuring for Planning}

With the change in perspective of new economic and social policies, an important expression has been developed to defend the idea that there is an important link between institutions and planning systems. In this expression, it is emphasised that the institutional approaches expressed by concepts such as institutional thickness' (Amin and Thrift, 1995), 'territorial capital' (Camagni and Capello, 2013: 1385) or 'untraded interdependencies' (Storper, 1997) have taken a key role in understanding social, cultural, economic and spatial subjects to explain the regional success. All these discussions regarding institutional approaches at the scale of firms and regions, as mentioned above, led to new perspectives on the region in parallel with new planning systems. New regionalism and the related planning systems have also changed the paradigm of institutional restructuring. This is because the impact of new economic systems has created opportunities for the development of new planning theories to solve problems in the urban and regional areas. It has also created the possibility of institutional restructuring within the scope of the new planning theory principles. In other words, theories such as the collaborative planning system, based on the communicative planning theory (Healey, 1997); new regionalism, which focuses on the network-based development of economic organizations or Third Way approaches (Amin and Thrift, 1995: 93-95, Storper, 1999: 210211); and institutional turning as a response to failures in the development of the nation-state, have simultaneously become part of urban and regional studies (Jessop, 1995,Phelps and Tewdwr-Jones, 2001). In the paradigm changes related to decision-making mechanisms in urban and regional studies, new models of organisation have been presented in many phases of the planning process, from the identification of policies to spatial decisions, from the managing process to the application process and from evaluations on a plan's effects to types of interference. These organisational models are based on the assumption that economic and regional development will be accomplished by sharing the authority and responsibilities of central management units with various actors from the local levels. It has been revealed that more flexible, realistic and effective evaluation of solutions to problems and increase complexity, especially in social, economic and spatial problems, requires successful organisa- tions derived from the local level. Researchers have attempted to explain the theoretical regulations and the arguments over the effects of successful organisations on urban and regional studies through institutional restructuring and paradigm changes in planning system. Namely, new institutional restructuring has been proposed by researchers as a pillar that completes the management aspect of regional policies, together with new regionalism' re-defining the region and new planning systems based on the communicative planning theories.

Institutional structure can be characterized by high levels of contact, cooperation, information exchange and sharply defined structures of coalition and collective representation to produce institutional 'thickness' or 'capacity' supported by formal arrangements such as laws, rules and organizations. They can also be characterized by informal contexts, such as behavioural roles, social and cultural norms, values and interaction patterns. This structure is, therefore, affected by the embeddedness in a specific context (Storper, 1999; Amin and Thrift, 1995; Allmendinger and TewdwrJones, 2000: 712). Institutional restructuring is based on the idea of supporting the planning system prepared at different levels ranging from the local scale to the national scale with the knowledge, opinion and experiences of institutions (formal and informal) at different levels and analysing the management process. The success of a particular region, thus, is dependent not only on the empirical research program but also on qualitative and quantitative research.

In short, a high level of interaction among institutions (networking, cooperation and information sharing), a strong corporate attitude, the development of regional agendas suggested by individual perspectives, and collective representation that will eliminate conflict and dilemma. These have been the main factors in the success of the planning system arising over economic and regional development policies at local and national level, especially with the declining of nationstate structure (Haughton and Counsell, 2004: 42, Tewdwr-Jones, 2012:222-226).

\section{Methodology}

As mentioned above, planning systems have been directly affected by the distinctions in economic and social policies at certain periods as the paradigms related to those periods reshaped the planning system. Since the 1960s, traditional spatial planning perspectives focused on identifying land-use decisions have become comprehensive rational planning systems 
under the influence of Keynesian economic systems, aimed at making holistic planning decisions at different administrative stages (Davoudi, 2009). However, the weakening of Keynesian economic policy against new liberal policies caused changes in spatial planning systems, and the development of planning tools slowed. However, in the 1990s, the interest in spatial planning began to increase again when the idea became dominant that evaluating regions from relational perspective would be more effective in terms of economic, social, cultural, and environmental development. Comprehending place from a relational perspective and new spatial planning perspectives focusing on producing problem-related solutions led to important differences related to the role of institutional structure, in which positivist discourse and spatial planning are dominant (Healey, 2006:526-27, Albrechts, 2008: 7-8).

During this process, in assessing the success or role of institutional structure for the planning process, the assumption that the flexibilities and abilities of formal and informal structures contribute to the success of the planning process began to be discussed from conceptual approaches, such as institutional change or institutional resilience (Oliveira and Vazquez, 2011: 66). In the face of rapidly changing urban and regional dynamics, it is assumed that flexibility in institutional structure will find solutions faster in usual or unusual situations. Especially in a traditional planning system seeking to transfer authority to the local level from the formal structure that is dominant in upper-scale planning and particualrly if informal institutions are included in the local planning process.

\section{Aim of the Study}

The aim of the study is to identify and discuss the effects of relational and institutional approaches, in the context of upper-scale planning experiences of Turkey. The study focuses on the institutional dimension of Turkish planning systems, particularly investigating whether new relational and institutional approaches can cope with upper-scale planning issues for development in Turkey. This is an important issue for Turkey because the country has been experiencing an institutional transformation process at all stages of planning systems with new regionalism since the 2000s. The institutional change based on the cooperation of basic factors in the planning process highlights the actor-based institutional structure, aiming to reveal necessary information or identify any inaccuracy in the process (Oliveira and Vazquez, 2011: 65-66). In other words, the aim of institutional change is to reveal the potential extent to which new power and political in- fluence, legal arrangements and cultural behaviour types whether affect the decision-making processes. Within this framework, this study examines the effects of institutional restructuring during the planning process in Turkey, especially on upper-scale planning experiences, success or failure, solution suggestions and administration.

With global trends, both the hollowing out of the nation-state and new conceptual-theoretical approaches in the planning literature led to new perspectives in Turkish planning systems. These developments paved the way for both a new planning system and institutional restructuring that will organize this planning system. Many instruments such as producing necessary resources at the local level, adding strategic dimension to spatial planning, abandoning normative principles, and the participation of formal and informal institutions in the process have been activated. In this period, the participation of the strategic dimension in the planning system, developing more flexible and problem-focused solutions and making an integrative planning perspective dominant, have been accepted to be basic principles. This article, thus, is focused on two hypotheses: "the richer is a region's institutional capacity, the more successful are its planning systems" and "the institutional capacity of a region consists of potential such as competitive, experiential, social, economic, cultural, and spatial features and legal regulations. Thus, the relational perspectives determined by this institutional capacity are a precondition of successful planning systems".

\section{Research Design and Method}

The principal issue of this study is to examine how relational and institutional perspectives can overcome planning problems across the regions of Turkey. In orde to test the hupotheses, this article is organised as follows:

First, the architectural structure of the planning mechanism in Turkey is analysed beginning with the 1960s. This is accepted as the beginning of upperscale planning studies. The study then describes the historical role of planning methods, regions/territories and institutions in upper-scale planning consisting of regional development plans, regional plans, provincial strategic developing plans and spatial plans according to breaking periods. This section attempts to explore the dominant institutional architecture, themes in planning and perspectives on planning processes.

In the second section, as done associated with relational and institutional dimension of planning system, 
it is discussed whether the new planning system brings a new perspective, especially to upper-scale planning studies. In addition, whether the abandonment of the traditional planning system will be a solution for regional development in Turkey. Since the 2000s, upperscale planning in Turkey has been analysed in terms of factors such as conceptual-theoretical perspectives, institutional-legal regulations, local sources, power relationships (social capital), and fragmentation. These factors has had an effect on planning processes.

Theoretical and Conceptual Approaches: What key issues have emerged in Turkish planning system since 2000 ? What have been the effects of these conceptual approaches on new planning systems and processes (e.g. spatial planning, sustainability, regional development, institutional structure)?

Institutional-Legal Regulation: What is the role of political decisions in the development of key issues in the Turkish planning system? What are the planning organization models, new institutions, NGOs and legal regulations? What is the effect of these structural developments on the planning process (e.g. legal regulations, institutional restructuring, political strategies and proposals)?

Local Sources and Power Relations, Fragmentation: Does the institutional capacity in the Turkish planning system have the potential to produce (location-specific) strategies focused on social-cultural, economic, spatial and social capital? What are the positive and negative effects of the role of actors on the process such as different voices and interests and their power relationships, political influence, and lobbying activities? What is the source of the conflicts and disruption between upper-scale planning types and responsible institutions in Turkey? How do the content and scope of the plans prepared for the same regions by different institutions differ? And finally, what are the results of the conflicts among the strategy, policy and spatial decisions of these plans?

\section{Relational and Institutional Dimensions of Planning Systems in Turkey}

It is possible to mention two breakpoints for planning experiences in Turkey. The first begins with the planned working period of the 1960s to the 1980s. Although the first upper-scale planning studies in Turkey were conducted by the Regional Planning Department founded under the frame of the Ministry of Environment and Urbanization (MEU) -the current name of this institution- in the 1950s, the establishment of State Planning Organization (SPO) in 1961 is considered the beginning of the plan period. The second breaking point is the period in which third way approaches began to dominate planning systems after the 2000s. However, the importance of neoliberal policies and communicative planning systems between 1980 and 2000 cannot be ignored with regard to planning systems in Turkey.

The regional development policy in Turkey has evolved through a number of stages since the 1950s. The spatial allocation of 'public investments' throughout the 1950s and the beginning of the 1960s. The launch of "regional development projects" through the financial support of international institutions during the 1960s. The beginning of the 1970s; the implementation of regional development projects for underdeveloped regions with a strong state incentive in the 1970s. And finally, a reorientation to the development projects for assisted regions since the 1980s (Eraydın, 2004: 139-40, Ozbek, 2010: 71). The common characteristic of these periods is that regional development practices and policies were conducted by the SPO to plan politics and strategies at the national and regional levels. This institution, neglecting the autonomous local and intermediary (between the local and central administration) planning institutions, played a dominant role in national and regional planning with five-year development plans. The development plans prepared in five-year periods have been the main reference for upper-scale plans. This is because of the pacifying of the Regional Planning Office by the SPO, spatial priorities in upper-scale planning were eliminated by development plans. Walter Isard's (1962) discovery of quantitative tools in regional development and positivist/rationality movements together with 'region science' began to show their effects in Turkey at the time. Quantitative analysis techniques in the studies conducted in Turkey and long-term planning approaches based on positivism and rationality and the calculations of projection have been adopted as a result of these movements (Davoudi, 2012: 430).

Planning studies in 1980-2000 aimed to determine the strategies and politics related to decreasing the inequalities among regions as a result of the crisis experienced in economic and social systems and the failures experienced in Keynesian economic politics. The plans have mostly been applied, although regional plans have not shown important differences in terms of institutional structure compared to the former period. The main approach of the period plans is regional development through revealing the regions' 
own potentials with the dominance of communicative planning approaches in terms of planning theories. New viewpoints in terms of planning theories in this period were not reflected in process of preparing regional development plans in Turkey except the Yesilirmak Regional Development Plan (YRDP). For this reason, the plans have been prepared as longterm plans based on positivist and rational perspectives. However, one of the most important issues is the emergence of institutions such as SARDA, EARDA, and EBSARDA. These institutions, although dependent on SPO, have managed the application process and prepared regional development plans with local actors during this period. The local offices of these institutions are a new experience in Turkey. SPO has also developed a study to determine regional borders by considering the economic, social, cultural and physical relationships of settlements from the town scale to the province scale, against the normative perspective, but it has not been accepted as a reference for the plans. Therefore, in some cases, two different plans have been determined for the same regions in addition to normative approaches.

Upper-scale planning studies have been intensively discussed worldwide and in Turkey after the 2000s. This period can be seen as one in which the Marxist viewpoint based on positivism and rationality was largely abandoned. The factors that have caused changes in the planning systems can be evaluated within the plans of this period and thus have embraced strategic planning systems due to new planning theory and politic reasons. In this period, new regional classification studies for regional development were determined to be a result of the coordinative studies conducted between SPO and Turk Stat in 2002. This is in parallel to the process of EU official candidatures in 1999. As a result of these studies, "Nomenclature of Units for Territorial Statistics (NUTS)" has been conducted at three different levels; 26 new statistical regional units at the NUTS 2 level have become accepted areas of regional studies, and provincial development plans at the level of NUTS 3 level have been pursued. Regional classification began the institutional structure of planning in the early 2000s, and the regional development policy of Turkey gained a new dimension in parallel to the restructuring efforts on the hierarchy of spatial planning. In addition, national plans are mainly characterized by a number of new policy areas: local devolution, regional prioritization, holistic development strategies, new rural planning strategies and subnational (provincial) planning.
As mentioned above, plans in this period, such as provincial development plans, regional plans and upper-scale spatial plans, have consisted of strategic priorities and clues for spatial decisions in Turkey. Provincial Development Plans were prepared by provincial governorships as a set of strategies aimed to reinforce the master plans within 17 provincial borders until 2005. However, these plans have become a mere inventory, in which evaluations related to the extant situation and the potential of the regions are conducted. On the other hand, not including spatial decisions in province development plans has limited the planning studies to a subjective and irrational framework.

After the year 2005, DAs, new legal regulations, NGOs and other factors began to be established for the redefinition and restructuring of the spatial planning system for the purpose of providing regional development at the NUTS 2 level. In 2006, together with the acceptance of the law 5449, the institutional structures of DA were determined, and the establishment process of DA in 26 regions at the NUTS 2 level began. Within this new institutional structure, the missions and responsibilities of DAs, which are accepted to be the most important actors in regional development, were determined within the framework of the related law. Since 2006, the SPO has preferred to use its authority to prepare regional plans with DAs. DAs conducted regional planning studies in 26 regions. Although the plans have prepared a parallel approach with theoretical backgrounds such as determination of the strategic missions, participation and cooperation of local actors, they lacked the expected impact on behalf of regional development. This is due to normative regions and conflict between institutional and local actors. At the same time, spatial planning studies have also been initiated by the $\mathrm{MEU}$, which has taken as references the strategies and politics determined by provincial development and regional plans.

Theoretical approaches, such as new regionalism, institutional restructuring and strategic-spatial planning, have shaped the planning systems in this period. These approaches have been seen as the reflection of an administrative organization with local devolution of government responsibilities to regional and local actors. In this process, the continuation of normative regions has been the main reason for the weak relationship between region-specific strategies and location. Namely, the architectural structures of upper-scale plans are summarized in Table 1. 
Table 1. Architectural structures of upper-scale planning systems in Turkey

\begin{tabular}{|c|c|c|c|}
\hline Criterion & $\begin{array}{l}\text { First Period } \\
(1960-1980)\end{array}$ & $\begin{array}{l}\text { Second Period } \\
(1980-2000)\end{array}$ & $\begin{array}{l}\text { Third Period } \\
(2000-\ldots . . .)\end{array}$ \\
\hline Dominant Policy Direction & Top-down & Top-down & Top-down and bottom-up \\
\hline Region & Uncertain demarcation & $\begin{array}{l}\text { Normative line of } \\
\text { demarcation for regional } \\
\text { planning }\end{array}$ & $\begin{array}{l}\text { Normative line of } \\
\text { demarcation for regional } \\
\text { planning }\end{array}$ \\
\hline Era & $\begin{array}{l}\text { Regional science, rationality } \\
\text { and positivist approach }\end{array}$ & $\begin{array}{l}\text { Neoliberalism, development } \\
\text { focused on regions }\end{array}$ & $\begin{array}{l}\text { Third way, new } \\
\text { regionalism }\end{array}$ \\
\hline $\begin{array}{l}\text { Dominant Approaches } \\
\text { to Regional Plan Making }\end{array}$ & $\begin{array}{l}\text { Regional economic development, } \\
\text { quantitative analysis with lengthy } \\
\text { periods (Public Sector Dominated) }\end{array}$ & $\begin{array}{l}\text { Regional economic development, } \\
\text { endogenous growth theories, } \\
\text { new quantitative analysis } \\
\text { (Public Sector Dominated) }\end{array}$ & $\begin{array}{l}\text { Regional competitiveness, } \\
\text { regional resilience } \\
\text { (Public Sector Dominated } \\
\text { and Partnership) }\end{array}$ \\
\hline Style of Plan & $\begin{array}{l}\text { Comprehensive and } \\
\text { multi-sectorial }\end{array}$ & $\begin{array}{l}\text { Comprehensive and } \\
\text { communicative planning }\end{array}$ & $\begin{array}{l}\text { Strategic with spatial } \\
\text { focus }\end{array}$ \\
\hline Form of Plan & Physical land use plan & $\begin{array}{l}\text { Strategic plans, } \\
\text { land use focus }\end{array}$ & $\begin{array}{l}\text { Strategic plans and spatial } \\
\text { planning, land use and } \\
\text { strategy focus }\end{array}$ \\
\hline $\begin{array}{l}\text { Dominant Regional } \\
\text { Institutional Architecture }\end{array}$ & $\begin{array}{l}\text { Central Government, State } \\
\text { Planning Organization (SPO) }\end{array}$ & $\begin{array}{l}\text { Central Government, State } \\
\text { Planning Organization (SPO), } \\
\text { South-eastern Anatolia Regional } \\
\text { Development Administration } \\
\text { (SARDA), Eastern Anatolia } \\
\text { Regional Development } \\
\text { Administration (EARDA), East } \\
\text { Black Sea Anatolia Regional } \\
\text { Development Administration } \\
\text { (EBSARDA) }\end{array}$ & $\begin{array}{l}\text { Development Agencies } \\
\text { (DA), some functional } \\
\text { devolution and Ministry } \\
\text { of Environment and } \\
\text { Urbanization }\end{array}$ \\
\hline Policy Instruments & $\begin{array}{l}\text { Public investments, financial } \\
\text { support, bureaucratic regulation }\end{array}$ & $\begin{array}{l}\text { Financial support, private } \\
\text { investments, bureaucratic } \\
\text { regulation }\end{array}$ & $\begin{array}{l}\text { Competition and } \\
\text { innovation }\end{array}$ \\
\hline Key Issues & $\begin{array}{l}\text { Physical renewal, well-balanced } \\
\text { development, welfare especially } \\
\text { on social issues }\end{array}$ & $\begin{array}{l}\text { Unbalanced development, } \\
\text { life quality, market-led growth }\end{array}$ & $\begin{array}{l}\text { Sustainability, clustering, } \\
\text { policy integration/ } \\
\text { disintegration, } \\
\text { competitive growth }\end{array}$ \\
\hline Tasks and Aims & $\begin{array}{l}\text { Regional development, regional } \\
\text { polarization, urban compulsion }\end{array}$ & $\begin{array}{l}\text { Regional inequalities, } \\
\text { enhancement of rural systems, } \\
\text { creation of regional centres }\end{array}$ & $\begin{array}{l}\text { Sustainable regional } \\
\text { development, regional } \\
\text { competitiveness }\end{array}$ \\
\hline
\end{tabular}

\section{Planning Matters in Turkey: A Discussion of Upper-Scale Planning}

The failure of 40 years traditional planning approaches to planning in Turkey created a tendency to adopt new planning systems, particularly under the scope of upper-scale planning studies and policies. This tendency has become the cause of many new developments, from conceptual and theoretical discussions to institutional legal regulations. Arising from the political environment related to planning agendas in Turkey, since the 2000s. Within this framework, it has been noted that the institutions responsible for planning and implementation have changed, the spatial scales have been redefined, and the types of spatial organization have been differentiated. Also, some definites have lost or gained importance as a result of the policies applied in spatial units. Although new approaches thought to be key for developing all the 
regions are decelerating the development of certain spatial units, they have also allowed some spatial units to compete at a global level. For this reason, planning with strategic, competitive, autocratic, non-normative and more flexible characteristics is accepted to be a key to economic and regional development.

In this parts is discussed in the context of three topic refering to relational and institutional approaches to solve ongoing planning issues in Turkey: theoretical and conceptual approaches, institutional-legal regulation (to discuss the scope and sufficiency of institutional-legal regulations related to planning policies and to determine the efficiency and role of the planning policies of actors), local resources and power relations, and fragmentation (to examine the efficiency of spatial, cultural, and economic factors and social and institutional capital during the planning processes of institutions within the scope of the planning system).

\section{Theoretical and Conceptual Approaches}

As mentioned above, planning systems have been changed by new economic expressions affecting the type of organization of spatial production. The attempt to restructure planning and administration, particularly in England (NLGN, 2005), has led to partly loosen the market-based policies that have dominated the first period of globalization and to recognize the state's certain responsibility. At this point, it has been seen a process to create regional administrative units with economic goals by transferring authority from central to local. This is done to define the area of reproduction for different social groups. In this process, new regional approaches to developing new solutions to more deeply address spatial problems and criticize the failures in regional development in the expression of the new economic policies have revealed new region descriptions to be the critical point of regional development (Eraydin, 2008: 12-13).

Since the 2000s, new region arising as a new administrative stage have begun to be seen the most important institutional actor of planning at the local level in Turkey. The newly define 'region' is also an important spatial scale of the strategic and spatial plans accepted as the new planning system of the 2000s. Therefore, during the last two decades, new region definitions and planning systems have hecticly taken their places in planning discussions in Turkey. Within this framework, as noted above, strategic and spatial planning studies from the regional scale to the provincial scale began to be prepared.

However, they offer that the conceptual discourses in Turkey have not been considered within the institutional structure responsible for planning-implementation or the scientific milieu, nor have these conceptual discussions been considered sufficiently in light of the economic, social, and spatial privileges of Turkey. Therefore, new region descriptions are seen as an important spatial scale for determination of sustainable and competitive strategy. However, it could not extend beyond a strict hierarchical division directed towards the classification and labelling of the regional areas that is generally based on symbolic scales. In other words, they have not aimed to found factual links of 'place', showing relational characteristics with the socio-cultural perspective and the administrative structure. Although space, shaping new production areas and describing local features in the globalization period (Hubbard and Kitchin, 2011: 9-10), can be a basic actor in planning-implementation processes, the normative regional classification tradition in Turkey continued its effect on planning experiences. For this reason, the idea of the region, which is defined as a politic tool for relational dimension of planning, must be able to form connections between 'place' and socio-cultural-economic concepts (Albrechts et.al., 2003:114-115). According to the new conceptual perspective, regions have been described in a new way: 'rather than the description of a fixed set of physical essences in an excessive existence, it is an expression of political desires and socio-cultural differences (Ozbek, 2012: 133)'. On the other hand, instead of re-arranging the artificial regions, it is necessary to try forming analytical zones to perform appropriate studies seeking the statistical data necessary for planning and wide ranging analysis techniques. The new planning systems must take over relational and functional analytical techniques instead of the predictive and analytical techniques where traditional positivist planning perception is dominant.

As emphasized above, in new planning system of Turkey, the struggles to maintain traditional positivist analytical techniques, the insufficiency of statistical data related to socio-cultural data and the lack of analytical zone classifications being the assessments of relational data are the main reasons showing up of similar planning decisions for different spatial units. Also, new planning systems in Turkey have led to keep away from being a politic tool of regional development due to the assessments as tools of economic growth obtained via including economic and social factors to planning by many different institutions and excluding the spatial dimension of this factors. 


\section{Institutional-Legal Regulation}

The struggles of the planning system in Turkey have gained importance in institutional-legal restructuring and redefinition of the territorial policies. This is the first example of provincial development plans. However, in this period, the "Provincial Development Plans" emerging from the result of endeavour is to find urgent and fast solutions for regional problems are not based on a specific justification in terms of institutional-legal regulations. Thus, this planning approaches performed by different institutions at different spatial scales reveal the uncertainty of planning and the institutional structure related to planning since the 2000s in Turkey. The absence of a legal basis for the provincial development plans made them problematic in terms of responsibility and possession. These plans have arisen because of the advice given to provincial governorships and other administrative units in terms of the policies estimated in the seventh and eighth development plans of the SPO and were not included in legal regulations related to the planning hierarchy. In other words, provincial development plans were prepared as a result of the provision in the eighth fiveyear national development plan and were mentioned neither in the legal regulations defining the duties and responsibilities of the institutions preparing the plans nor in the planning regulation.

Unlike provincial development plans, the attempt by Turkey to enable regional issues within the scope of the EU integration process caused an important transformation of institutional and legal regulations during planning-implementation processes. As clearly seen from the National Strategy Document defined specifically within the scope of the EU integration process, the fact that one of the negotiation headings is the topic of regional development reveals the importance given to the institutional-legal regulations. In this framework, the first step of institutional restructuring and legal regulations was the regional classification of NUTS to identify spatial scales for both EU grant programs and region-scale plans by SPO and Turk Stat in 2002. These classifications are simultaneously accepted as the territory of planning. The spatial scale defined as the territory of the DAs (Development Agencies) is emerging as the most important actor in planning systems of Turkey since the 2000s. Therefore, in 2006, DAs at the NUTS 2 level became established along with relevant legal regulation as local units of SPO. As a result, the institutional restructuring was completed by 2009. According to this legal regulation, the responsibility for preparing upper-scale planning to DAs has not been given by the
SPO in contrast to international examples. Although legal regulation defining the duties and responsibilities of the DAs consists of project-focused activities such as identifying the resources and opportunities of the region. However, with the temporary authority given by the SPO, DAs have prepared regional scale plans since 2010. These plans have been indicated as upper-scale plans following the development plans in the planning hierarchy and have aimed to improve ideas for increasing the problem-solving capacity of sub-scale plans.

Spatial planning experiences getting involved in planning practice since the mid-1980s in terms of the institutional and legal basis, have aimed to put forward a new planning approach with a new institutional structure and perspective since the 2000s. The legal basis of spatial plans, namely the Environment Regulation Plan, was defined in law number 3194. It was accepted as the upper-scale of master plans prepared at the local level. In this framework, Environment Regulation Plans in 17 regions were prepared by MEU. In these plans were used completely traditional planning techniques, such as analytical and positivist analysis processes and land-use decisions, which have remained distant from the purpose of strategic planning.

Within the framework of these evaluations, planning systems showing up the institutional-legal regulation process for planning-implementation processes since $\mathbf{2 0 0 0}$ have indicate that there is no planning approach to reveal the relational reasons between strategic policies and spatial decisions. In other words, there is no coordination between provincial development plans, regional plans prepared using strategic planning approaches, and spatial plans prepared using traditional land-use decisions.

The problems can be evaluated in the framework of the planning-implementation process and spatial scales. The legal regulations to which planning was subject after 2000 have developed as a reflection of the restructuring process of the central administration. This process has been incorporated into systematic planning extremely fast and without an understanding of the reasons and results. The new institutions and legal regulations have not been a remedy for planning problems and have even caused planning disputes in Turkey. Institutional and legal regulations remained far from developing new instruments and arrangements for basic planning and for topics such as which actors will take over the duties of the planning processes for what reasons, what the content of the plans will be, on which relational matters the association will be provided, and how the planning-implementation association 
will be provided. The legal regulations mostly consist of texts defining the duties and responsibilities of the institutions in connection with planning. For this reason, legal regulations led to important gaps related to planning processes. The 'Provincial Development Plans' that began to be prepared in the early 2000s is the most significant example. These plans have niether legal basis and nor identified framework in terms of either spatial scales or planning stages and approaches. A similar gap exists in the legal regulations related to regional and spatial plans prepared in similar terms. As a result, the understanding that 'when the foresight and analytical techniques that dominate traditional positivist planning approaches are applied correctly, the future will be identified in a certain way (Ogilvy, 2002)' became dominant in all of the plans made in this process. In the identification of spatial scales, the normative viewpoint provided opportunities for positivist analytical processes (Davoudi, 2012: 430). Planning problems in Turkey have been identified according to the borders based on geographic and analytical approaches. However, for the analytical features identified by the legal regulations of regions with various problems, such as earthquake zones, water protection areas, basin areas, natural protection areas, urban concentrations, and rural areas. It is necessary to identify spatial privileges, planning-implementation instruments and conceptual structure. During this process, the necessity of performing all-inclusive and time-consuming financial, geographic, sociological and statistical studies to define new analytical spaces has been ignored.

The necessary planning approaches and legal regulation will require institutional restructuring and cooperation between strategic and spatial decisions, in which the new spatial scales are defined for the analytical processes and techniques that address innovation and relational reasons. For legal regulations to describe the planning hierarchy and relationship between plans, organizational models associated with planning and implementation must be clearly determined. In recent years, although the Directorate of Spatial Planning of MEU has attempted to make strategic spatial plans, so far no single institution's initiative able to eliminate this problem suffeciently. The institutional and legal regulation problems of upper-scale plans in Turkey are not one-dimensional and cannot be wholly solved in the planning scale. Therefore, re-conceptualization of the administrative area and modification of all mechanisms of planning stages in the territory are necessary to begin to address this problem. As institutional-legal regulations are the main factor affecting negative planning for spatial units with differences ranging from geographical features to economic and social development status and from human capital structure to local resources and accessibility.

\section{Local Sources, Power Relations and Fragmentations}

Institutional structure in planning has broad effects because of the discourse of governance in new economic policies, such as decreasing the role of the state in social-economic relationship management, the discovery of informal actors, and service delivery (Davoudi and Evans, 2005: 495-496). Regarding the concept of governance, which can be considered to reduce the pressure of state power and to increase the pressure on local actors, planning systems have begun depends on various elements such as local factors, resources, internal dynamics, institutional capacity, and social capital in Turkey. The cooperation of actors such as the governorship, NGOs, universities and municipalities in provincial development plans and of centrallocal governments, development agencies, NGOs, universities and research institutions, various associations and communities in planning studies as well as cooperation between central-local governments and scientific institutions have shown the role of governance in planning systems.

In this connection, although DAs as a new form of governance aims to provide the effective using of local sources and remove the fragmentations among actors in the region for helping to regional development by increasing the region's competitiveness through a multi-actor collaborative and participative structure, they could not show sufficient success either in the use of local and regional resources or in the production of regional strategy, policy, and spatial decisions. One of the main reasons is that the role of the central government is not decreasing but is redefined. In other words, the governmental system continues to be more dominant than local governance in the planningimplementation process. The central government is determinative in the decision-making process. On the other hand, planning systems focused on local actors, politics and strategy is far from solving the problems of different regions of Turkey with different levels of social and human capital potential development. The regions with low human and social capital potential are unable to determine strategies for taking advantage of local resources and therefore imitate other regions. This situation leads to similar planning policies at different spatial scales and hinders the success of planning systems. In particular, regions with low levels of social capital or high levels of bonding social capital (friendship, kinship, and familiarity) show an inhibi- 
tory effect on regional development because strategic decisions made on these criteria rather than scientific assumptions can lead to debates and conflicts among actors. The 2014 report prepared by the State Supervisory Council of the Republic of the Turkey for DAs has emphasised this situation. This report also expresses the need to consider regional characteristics in regional development policies and to explore agency models. In which the leader's guidance addresses the disadvantages of the region and supports entrepreneurship, investment, production, product diversity and employment of both technical and financial aspects for regions that are weak in competitiveness and development potential. This offers a suggestion that should be given a fillip to local sources allowing innovation, clustering, branding, internalization, and cooperation networks in developed regions. It is also emphasised that organisational structure, size, units, human resource profiles, personal rights, and basic functions of development agencies should be revised and re-shaped according to the regional characteristics.

This power relations and conflicts could occur among actors because of gaps in the legislation in planning and implementation process. The Provincial Governor and the Provincial Special Administrations responsible for strategy plans. The Ministry of Development and the Development Agencies responsible for regional planning. The Ministry of Environment and the Ur- banization Directorate General of Spatial Planning responsible for spatial planning. These authorties have not coordinated in their strategic and spatial decisionmaking processes. This problem demonstrates one of the gaps in institutional-legal regulations. On the other hand, because the facilities of regional development administrations that emerged after the 1980s, such as SARDA, EARDA, and EBSARDA, as well as Konya regional development administration, which emerged after 2010, all wish to plan areas of responsibility, different institutions produce plans for similar spaces. Thus, the upper-scale planning process in Turkey is far from producing strategies, and spatial planning decisions because of the conflicts and disputes among local actors and among the institutions responsible for planning (as shown in Figure 1. below).

As a result, uncertainties regarding spatial scales in planning systems are an important problem that hinders the effective reflection of local resources and modification of the relationship and cooperation between actors. In this context, to ensure coordination between upper-scale plans, determine visions for spatial scales at the national level and a governance model that eliminates conflicts and considers actors, supporting regions with low human-social capital potential will be the starting point for regional issues and planning matters. Namely, the allocation of power among the institutions responsible for planning in Turkey are important to un-

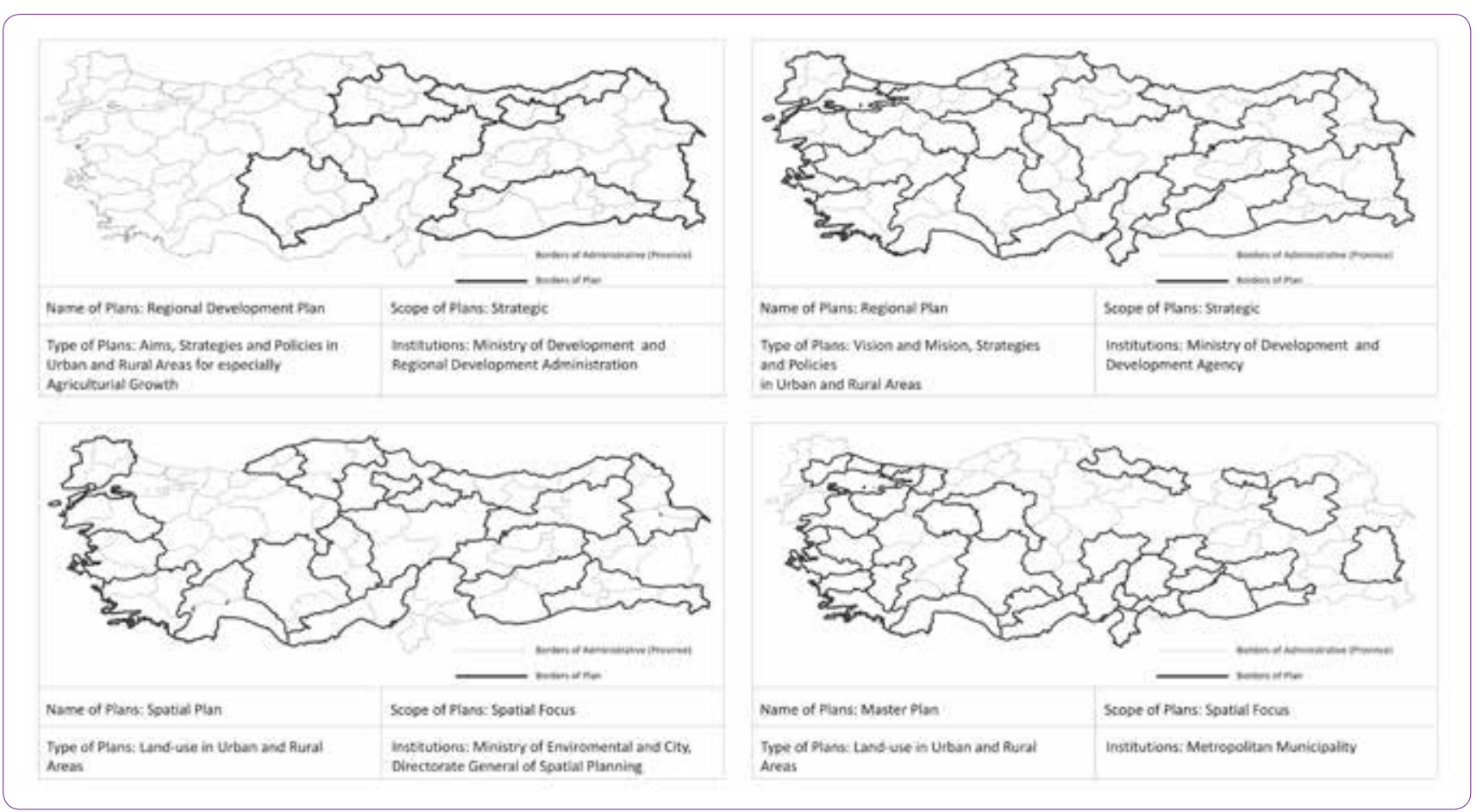

Figure 1. Planning areas and institutions in Turkish upper-scale planning. 
derstand why a new power structure is necessary for the better performance of planning practices.

\section{Conclusion}

This study explored the effects of relational and institutional dimensions in the success of upper-scale planning, evaluating them as keys to regional matters in Turkey. In this context, problems and solution approaches regarding existing planning processes were evaluated through reviewing the successes and failures of upper-scale plans from a relational and institutional perspective in Turkey. The evaluation of Turkey's experiences throughout the 1960s with upper-scale planning process in general showed that institutional and conceptual discussion was not sufficiently internalised. In addition, necessary institutional-legal regulations could not be improved. Likewise, necessary application-monitory-evaluation ordering could not be assembled in the planning systems. Although there are richer upper-scale planning studies in the 2000s, with re-conceptualization of space in economic-social paradigms and political discourse, diversification of planning thought and perspective, and definition of governance models and actors, there are issues both due to the lack of relationship and interactions between actors and plans, and because strategic-spatial decisions about new regional development agenda could not be developed. Despite the fact that the content and scope of planning system are diverse subjects, upperscale planning matters in Turkey can be evaluated in three phases in terms of institutional approaches.

The first subject is the need to resolve spatial scales and planning territory. In addition to geographical definitions, relational and analytical definitions of the concept of region or place evaluated as an organism consisting of economic, social, cultural, and environmental values will be a starting point for the solution of spatial scaling problems. Statistical and descriptive studies will render a clearer analysis of health and safety. Also, re-evaluation of institutional-legal regulations and the relational hierarchy between plans has a vital role in the problem of regional issues. In this context, planning systems should be constructed to provide coordination between plans producing strategic decisions and plans producing spatial decisions. There should be a new legal-institutional structure that can relate strategic and spatial plans at all stages as analytical processes of plans and alternative plans, implementation processes and governance models. Conflicts of authority among institutions responsible for planning-implementation processes should be eliminated. Thirdly, governance models that can minimize power relations and conflicts among actors should be presented.

In a nutshell, new institutional-legal regulations associated with planning-implementation unity are needed in Turkey. The inability to date to establish integrity has played an important role in perpetuating problems at the regional and interregional levels. Although some efforts have been made, regulations to ensure their integrity could not be established thus far. In this framework, not only the goal of economic development but also the demands and expectations of society and actors, the potentials and needs of society, cooperation between central and local governments, and the topics of planning should not only be evaluated and but also capable of transfer across applications.

\section{Acknowledgements}

The work was funded by The Scientific and Technological Research Council of Turkey, 2219 International Post Doctoral Research Fellowship Programme. I would like to thank Prof. Simin Davoudi for her excellent and valuable suggestions during research at Newcastle University, UK.

\section{References}

Albrechts, L. (2004) "Strategic (spatial) planning re-examined". Environment and Planning B: Planning and Design, $31,743-58$.

Albrechts, L. (2008) "Strategic spatial planning revisited experiences from Europe". 3rd Regional Development and Governance Symposium 27-28 October 2008. Mersin.

Albrechts, L., Healey, P. and Kunzmann, K.L. (2003) "Strategic spatial planning and regional governance in Europe". Journal of the American Planning Association, 69, 113-29.

Allmendinger, P. and Tewdwr-Jones, M. (2000) "Spatial dimensions and institutional uncertainties of planning and the'new regionalism'". Environment and Planning C: Government and Policy, 18, 711-26.

Amin, A. (1999a) "An institutionalist perspective on regional economic development". International Journal of Urban and Regional Research, 23, 365-378.

Amin, A. (1999b) "The Emillian model: institutional challenges", European Planning Studies, 7, 389-405.

Amin, A. and Thrift, N. (1995) Globalisation "institutional thickness" and the local economy. edt.: P. Healey, S. Cameron, S. Davoudi, S. Graham and A. Madanipour, in: Managing Cities: The New Urban Context, 91-108, Chichester: Wiley.

Baker, M. (1998) "Planning for the English regions: a review of the secretary of state's regional planning guidance". Planning Practice and Research, 13, 153-69.

Brenner, N. (2003) "Metropolitan Institutional reform and the rescaling of state space in contemporary Western Europe". European Urban and Regional Studies, 10, 297324. 
Camagni, R. and Capello, R. (2013) "Regional competitiveness and territorial capital: a conceptual approach and empirical evidence from the European Union". Regional Studies, 47, 1383-1402.

Cooke, P. and Morgan, K. (1996) Growth regions under duress: renewal strategies in Baden-Württemberg and Emilia-Romagna, edt.: A. Amin, N. Thrift, in: Globalization, Institutions and Regional Development in Europe, London: Oxford University Press, 91-117.

Cumbers, A., MacKinnon, D. and McMaster, R. (2003) "Institutions, power and space; assessing the limits to institutionalism in economic geography", European Urban and Regional Studies, 10, 325-42.

Davoudi, S. (2009) "Scalar tension in the governance of waste: the resilience of state spatial Keynesianism". Journal of Environmental Planning and Management, 52, 137-56.

Davoudi, S. (2012) "The legacy of positivism and the emergence of interpretive tradition in spatial planning". Regional Studies, 46, 429-41.

Davoudi, S. and Evans, N. (2005) "The challenge of governance in regional waste planning". Environment and Planning C: Government and Policy, 23, 493-517.

Eraydın A., (2004), Bolgesel kalkinma kavram, kuram ve politikalarinda yasanan degisimler, in: The First Symposium on Urban Economic Studies (KEAS 2003), TR. Prime Ministry State Planning Organisation, Ankara, 126-43.

Eraydin, A. (2008) "Planlamadan uygulamaya”. 3rd Regional Development and Governance Symposium 27-28 October 2008. Mersin.

Hadjimichalis, C. (2006) "Non-economic factors in economic geography and in 'new regionalism': a sympathetic critique", International Journal of Urban and Regional Research, 30, 690-704.

Haughton, G. and Counsell, D. (2004) Regions, spatial strategies and sustainable development. London: Routledge.

Healey, P. (1997) Collaborative planning: shaping place in fragmented societies, London: MacMillan.

Healey, P. (2006) "Relational complexity and the imaginative power of strategic spatial planning". European Planning Studies, 14, 525-46.

Higano, Y., Nijkamp, P., Poot, J. and Wyk, K. (2002) Trends and regional policies in the new economy: an overview. edt.: Y. Higano, P. Nijkamp, J. Poot and K. Wyk, in: The Region in the New Economy: An International Perspective on Regional Dynamics in the 21st Century. England: Ashgate.

Hubbard, P. and Kitchin, R. (2011) Introduction. edt: P. Hubbard, R. Kitchin and G. Valentine, in: Key Thinkers on Space and Place, London: SAGE.

Isard, W. (1962) Methods of regional analysis: an introduction to regional science. Cambridge: MIT Press.

Jessop, B. (1995) “The Regulation approach, governance and post-fordism: alternative perspectives on economic and political change?". Economy and Society, 24: 307-33.

Keating, M. (1997) The political economy of regionalism. edt.: M. Keating and J. Loughlin, in: The Political Economy of Regionalism, London: Frank Cass, 17-40.

Keating, M. (1998) Is there a regional level of government in Europe?. edt.: P. Le Gales and C. Lequesne, in: Regions in Europe, London: Routledge, 11-29.

Lipietz, A., (1986) New tendencies in international division of labour: regimes of accumulationand nodes of regulation, edt.: A. Scott and M. Porter, in: Production, Work and Territory, Londra: Allen Unwin, 16-35.

Lovering, J. (1998) Theory led by policy: the inadequacies of the 'new regionalism' in economic geography illustrated from the case of Wales. Paper presented at the Economic Geography Research Group Seminar-Institutions and Governance, 1998 Department of Geography UCL, London.

MacLeod, G. (2001) "New regionalism reconsidered: globalization and the remaking of political economic space". International Journal of Urban and Regional Research, 25, 804-29.

North, D. (1990) Institutions, Institutional Change and Economic Performance. New York: Cambridge University Press.

Ogilvy, J.A. (2002) Creating better futures: scenario planning as a tool for a better tomorrow. Oxford: Oxford University Press.

Oliveira, C. and Vazquez, I. (2011) "Territorial governance in Portugal: institutional change or institutional resilience?. The Planning Review, 47, 64-76.

Ozbek, O. (2010) "Development agencies and institutional restructuring in Turkish regional development policy". edt.: s. Korenic and M. Sasek, in: Spatial Economy-Contemporary Determinants, trends and Tendencies, Polish Academy of Science-Committee for Spatial Economy and Regional Planning, Warsaw: 70-71.

Ozbek, O. (2012) “Turkiye'de normative bolgeler ve il gelisme planlamasi". Amme Idaresi Dergisi, 45: 129-54.

Phelps, N. and Tewdwr-Jones, M. (2001) "Globalisation, regions and the state: exploring the limitations of economic modernisation through inward investment". Urban Studies, 38, 1253-72.

Pike, A. (2009) Introduction: whither regional studies?. edt.: A. Pike, in: Whither Regional Studies?, England: Routledge.

Storper, M. (1997) The regional world: territorial development in a global economy. New York: Guilford Press.

Storper, M. (1999), "The resurgence of regional economies, ten years later: the region as a nexus of untraded interdependencies", edt: J. Bryson, N. Henry, D. Keeble, R. Martin, in: The Economic Geography Reader, New York: John Wiley and Sons, Ltd., 209-15.

Tewdwr-Jones, M., (2012) Spatial planning and governance. United Kingdom: Palgrave MacMillan.

The New Local Government Network, NLGN. (2005) Seeing the Light? next steps for city regions. London.

Wheeler, S. (2002) "The new regionalism: key characteristics of an emerging movement". Journal of the American Planning Association, 68, 267-78. 